\title{
INVENTIVE THINKING 21ST CENTURY SKILLS AMONG PREPARATORY COURSE SCIENCE STUDENTS
}

\author{
Punia Turiman ${ }^{1}$, Kamisah Osman ${ }^{1 *}$ and Tengku Siti Meriam Tengku Wook ${ }^{2}$ \\ ${ }^{1}$ Faculty of Education, Universiti Kebangsaan Malaysia, 43600 Bangi, \\ Selangor, Malaysia \\ ${ }^{2}$ Faculty of Information Science \& Technology, Universiti Kebangsaan Malaysia, \\ 43600 Bangi, Selangor, Malaysia \\ *Corresponding author: kamisah@ukm.edu.my
}

Publication date: 23 December 2020

To cite this article: Punia Turiman, Kamisah Osman, \& Tengku Meriam Tengku Wook. (2020). Inventive thinking 21 st century skills among preparatory course science students. Asia Pacific Journal of Educators and Education, 35(2), 145-170. https://doi.org/10 .21315/apjee2020.35.2.9

To link to this article: https://doi.org/10.21315/apjee2020.35.2.9

\begin{abstract}
Inventive thinking is one of the constructs in 21 st century skills. The $21 \mathrm{st}$ century skills are the skills needed by future workforce in the new global economy that driven by knowledge, technology and innovation. Inventive thinking comprises of six elements which are flexibility, self-regulation, curiosity, creativity, risk taking and higher order thinking. This study aimed to measure the level of inventive thinking among preparatory course science students at two MARA colleges. Besides, this study has also examined the effect of gender and previous school location on the level of inventive thinking. This quantitative approach study employed 21 st century skills instrument. Total of 240 respondents of first year students that attended to these colleges have answered the questionnaires. Findings revealed that the levels of all subconstructs in inventive thinking were high except for creativity that revealed a moderate level. Meanwhile, there were no effects of gender and former school location on the levels of inventive thinking. However, these findings have given insight that the level of creativity should be enhanced. Science students should master all subconstructs in inventive thinking in order to become great innovators who can contribute to the nation's prosperity.
\end{abstract}

Keywords: Inventive thinking, 21st century skills, preparatory course, science students, creativity 


\section{INTRODUCTION}

As technology is rapidly changing the way people live in this digitally enabled economy, the skills required for the workforce are also changing. The future economy is looking for the workforce who are able to adapt with complexity and diverse challenges (Daly, Mosyjowski, Oprea, Huang-Saad, \& Seifert, 2016; Koh, Chai, Wong, \& Hong, 2015; Newton \& Newton, 2014). They are expected to access, analyse and synthesise the information, creative to innovate, demonstrates effective communication skills and high cooperation skills (Boyaci \& Atalay, 2016). enGauge 21 st century has way before established 21 st century skills (North Central Regional Educational Laboratory [NCREL], 2003), as the skills needed for the workforce in order to be successful and competitive at workplace and also life (Häkkinen, Järvelä, Mäkitalo-Siegl, Ahonen, Näykki, \& Valtonen, 2016; Neubert, Mainert, Kretzschmar, \& Greiff, 2015; van Laar, van Deursen, van Dijk, \& Haan, 2018). Twenty-first century skills comprise of four main constructs namely digital age literacy, inventive thinking, effective communication and high productivity. Meanwhile, the partnership for 21 st century learning has identified four skills themes consist of: (i) core subjects; (ii) learning and innovation skills; (iii) information, media and technology skills and (iv) life and career skills (P21 Skills, 2011). Therefore, assessing the employees' 21st century skills will benefit to organisations which characterised by technology advancement and complex knowledge (Kamprath \& Mietzner, 2015). The 21st century skills have become the top agenda for academics, business leaders and policy makers across the globe.

In this 21 st century, the economy of a country is much based on the innovation produced by its citizen. Innovation is to go beyond what we are presently doing and generate a novel idea that aids our job in a new manner (Serdyukov, 2017). Creativity is generating novel and beneficial ideas in any dimension while innovation is implementing the creative ideas within an organisation (Amabile, 1996). Modern work in this 21 st century gives priority to creativity (Egan, Maguire, Christophers, \& Rooney, 2017; Greiff, Niepel, \& Wustenberg, 2015) in numerous fields including technology, business and entrepreneurship (Cooper, 2000; Zimmerer \& Scarborough, 2008). Kivunja (2014) suggested that the essential skills for creativity and innovation are the ability to solve problem in new manner, to invent new technologies and to produce new applications from the existence technologies. Meanwhile, the key for an inventive society requires a multidimensional approach to empower the education system so that it nurtures learner's autonomy, critical thinking, creativity, self-efficacy and enhances a new paradigm culture that supports innovative education (Serdyukov, 2017). 


\section{LITERATURE REVIEW}

Inventive thinking is one of the main constructs in 21 st century skills. It is a cognitive process that employs thinking in a creative and critical way during problem solving to generate innovative or specially designed solutions (NCREL, 2003). It comprises six sub-constructs which are flexibility, self-regulation, curiosity, creativity, risk taking and higher order thinking as shown in enGauge 21 st Century Skills Model in Figure 1.

\section{enGauge 21st Century Skills}

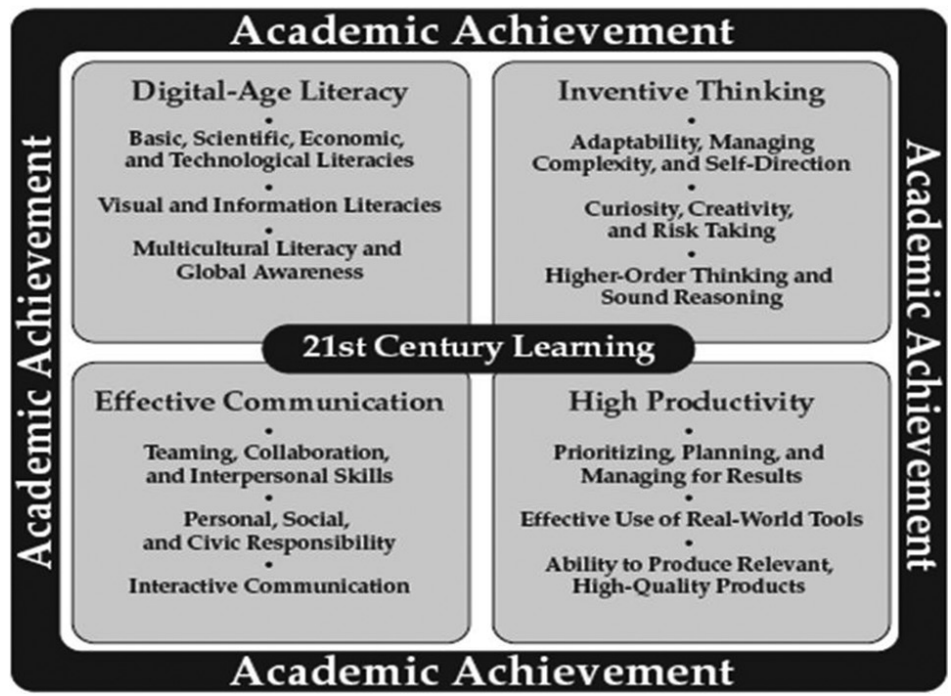

Figure 1. enGauge 21st century skills model (Source: NCREL, 2003)

Flexibility refers to an ability to alter the method of thinking, attitudes and actions in completing the given task within a limited time and resources. Self-regulation means an ability to set goals, make strategies to achieve the goals, manage time and evaluate the achieved goals independently. Curiosity is referred to the desire to know and this is a fundamental element to flourish lifelong learning. Creativity means using the imagination to generate new and original ideas, solutions or products. Risk taking is meant as the willingness to place something highly valued in a position where it could be exposed to loss or damage. While, higher order thinking is described as a creative problem-solving process that gives informed, sound, thoughtful, judgement and conclusion. These six sub-constructs should be cultivated among the students, so that they are able to face uncertain and challenging situations at workplace as well as life in this globalised digital era. 
Despite the importance of higher order thinking which is acknowledged by government and teachers, the implementation has been inadequate, as employers still find employees with inadequate critical thinking capability (Jerome, Lee, \& Ting, 2017). Furthermore, majority of students fail to apply the element of higher order thinking skills (HOTS) such as critical thinking and problem solving that were learned in class into the actual context (Seman, Yusoff, \& Embong, 2017). Besides inadequate critical thinking, studies also revealed the low creativity among university students. Alias (2009) discovered a low level of creativity of students in the science programme at the Faculty of Education, which is the potential to affect the process of teacher delivery of knowledge in the classroom later. As a result, efforts should be initiated to the concern prospective science teachers to enhance their creativity in order to encourage creative learning environment in producing science students who can develop their creative and entrepreneurial knowledge. Another related study was conducted by Saad (2009) to investigate the practice of science students' creativity and innovation in implementing the Final Year Project (FYP) at university. Findings indicated that there were practice of creativity and innovation however less control of these elements during the implementation of FYP. Besides, Ayob, Hussain, Mustaffa and Abdul Majid (2012) measured Electrical Engineering undergraduate students' creativity who participated in a national robotic design competition. The Torrance Test of Creative Thinking (TTCT) was employed and distributed to 38 students. The findings revealed that $67 \%$ of the students have Average Standard Score (ASS) more than 100 . This means that the creativity level of students was average. Meanwhile Jiboye, Salaudeen, Adejumo and Aikomo (2019) revealed that there was no significant correlation between creativity and mental ability among high achieving students. These crucial skills that 21 st century learners should possess are the subconstructs of inventive thinking that are going to be the main focus of this study.

A number of researchers have studied inventive thinking in these past few years. A study was employed by Sokol, Oget, Sonntag and Khomenko (2008) which aimed at the development of student's inventive thinking skills through Thinking Approach (TA) in language teaching and learning. The study was conducted among upper secondary students of two schools in Latvia. The results of the study suggested that students working with the TA demonstrate a significant increase in inventive thinking skills in comparison with the control group $(t=3.32$, $p=0.001$ ) thinking skills with regards to gender and school location. The female students performed better in their science inventive thinking skills compare to male students. Besides that, Abdullah and Osman (2010) employed a study to measure the level of inventive thinking among 500 primary school students in Brunei. The highlights of the study were pupils' low mean scores on creativity, 
higher order thinking skills and sound reasoning. It was also reported that there were significant differences in the level of inventive thinking with regard to gender and school location. In another study, Soh (2011) investigated the effect of school location and gender on the level of inventive thinking among 760 Form Four Physics students (16-17 years old) from 14 schools in Selangor state, Malaysia. The findings revealed the high level of inventive thinking. All sub-constructs of inventive thinking were at a high level except for risk taking that revealed a mediocre level. For the effect of school location, it was found that there was a significant difference in the level of inventive thinking based on school location. Rural school students scored higher mean compared to urban school students. However, there was no significant difference in the level of inventive thinking based on gender.

On the other hand, Arsad (2011) also carried out a survey to determine the level of inventive thinking based on gender and school location among 745 Form Four Biology students in the same state of Selangor. It was reported that the level of inventive thinking was mediocre. All sub-constructs were at a mediocre level except for self-regulation that showed a high level. In contrast to Soh (2011), the findings indicated that there was a significant difference based on gender in which female students outperformed their counterpart male students. However, school location gave no effect on the level of inventive thinking. A study was also conducted by Sahak, Soh and Osman (2012) to measure the level of inventive thinking among 660 students in five secondary schools in the state of Kelantan, Malaysia. The findings from the study demonstrated that six out of seven subconstructs measured namely flexibility, higher order thinking, self-regulation, curiosity, creativity, spiritual norms and values were at a high level. However, one sub-construct which was risk taking showed a medium level. Inferential analysis indicated that gender, stream (science or non-science) and location gave significant effects on the levels of inventive thinking among the students. This gave an implication that the level of inventive thinking was not limited to be developed among only the students in the city. Majority would expect that the exposure of urban students on the current needs of these 21st Century Skills is higher than the rural students is proven incorrect. Rural students in this study showed their potential too to compete with students from urban schools in terms of building inventive thinking in themselves. Similarly, Naderi, Abdullah, Aizan, Sharir and Kumar (2009) found no significant difference in creativity based on gender among undergraduate students. Meanwhile, there was no evidence on the effect of gender and racial on the creativity (Baer \& Kaufman, 2008; Kaufman, Baer, Agars, \& Loomis, 2010). Meanwhile, Saido, Siraj, Nordin and Al-Amedy (2015) measured the level of higher order thinking skills among 7th grade science 
students in the Iraqi-Kurdistan region. The findings demonstrated that there was no significant difference in the level of higher order thinking skills between male and female students.

Besides cross-sectional studies on inventive thinking, several researchers carried out instructional design studies to inculcate inventive thinking in their science lessons. Husin et al. (2016) have developed BITARA STEM Module for Form Two students. The researchers employed Project Oriented Based Learning (POPBL) strategy in integrated STEM education programme. The aim of this project was to assess the effect of this POPBL in integrated STEM education programme on students' 21 st century skills including inventive thinking. The outcome showed that the level of inventive thinking for the treatment group was higher than the control group. Most recently, Samad and Osman (2017) have developed EkSTEMiT Learning Module to foster inventive thinking for a quasiexperimental group of Form Four chemistry students. Based on Creative Design Spiral Model, the researchers embedded inventive thinking in Electrochemistry lesson.

Despite these published data on inventive thinking among primary school students and mainly secondary school students, there is little published data on the level of inventive thinking among preparatory course or post-secondary students. Furthermore, the sample in this study would involve high achieving students who were majoring in science. As a result, this study is carried out to close this gap since the students would be more matured and expected to attain higher level of inventive thinking as they attend post-secondary education. In addition, the researchers also seek to determine the effects of gender and previous school location on their levels of inventive thinking as findings from past studies shown inconsistencies trend from these factors. By knowing students' level of inventive thinking, it would be easier for the policy makers and teachers to prepare the teaching strategy that able to enhance their inventive thinking.

\section{METHODOLOGY}

This study aimed to measure the level of inventive thinking among preparatory course science students using survey method. Besides, this study also aimed to investigate the effects of gender and previous school location on students' level of inventive thinking. Inventive Thinking 21st Century Skills Instrument (Osman \& Marimuthu, 2010; Osman, Soh \& Arsad, 2010; Soh, Osman \& Arsad, 2012) was employed in this study. Validity is referring to the appropriateness, correctness, meaningfulness and usefulness of the specific inferences' researchers 
make based on the data they collect (Fraenkel, Wallen \& Hyun, 2013). A fivepoint Likert ranging from highly relevant (1) to not relevant (5) scale was used to allow experts to evaluate the face and content validity of the instrument (Arsad, Osman \& Soh, 2011). Meanwhile, reliability refers to the consistency of the scores obtained by an instrument should at least 0.70 and preferably higher (Fraenkel et al., 2013). Pilot study is carried out to obtain the reliability index of the instrument. Thirty Year Two students of science foundation programme but different cohort from this study were involved in the pilot study. There were 35 items in total and the responses from the students were used to calculate the value of Cronbach Alpha. Although the values of Cronbach Alpha for risk taking and higher order thinking were less than 0.70, overall Cronbach Alpha was 0.78. This implicated that the instrument was highly reliable as the overall Cronbach Alpha was greater than 0.70 . The number of items and values of Cronbach Alpha are summarised in Table 1.

Table 1. Inventive thinking 21 st century skills instrument

\begin{tabular}{lccc}
\hline Subconstruct & Number of items & Item number & Cronbach Alpha \\
\hline Flexibility & 5 & D1-D5 & 0.84 \\
Self-regulation & 8 & D6-D13 & 0.88 \\
Curiosity & 5 & D14-D18 & 0.82 \\
Creativity & 4 & D19-D22 & 0.82 \\
Risk taking & 7 & D23-D29 & 0.64 \\
Higher order thinking & 6 & D30-D35 & 0.67 \\
Inventive thinking & 35 & & 0.78 \\
\hline
\end{tabular}

This questionnaire used Likert scale ranging from 1 to 5 ( 5 for strongly disagree, 4 for disagree, 3 for neutral, 2 for agree and 1 for strongly agree). The inventive thinking was then categorised into three levels based on the mean score as demonstrated in Table 2. Low level for mean 1.00-2.33, mediocre level for mean 2.34-3.66 and high level for mean 3.67-5.00.

Table 2. Level of inventive thinking

\begin{tabular}{cc}
\hline Mean $(\mathrm{M})$ & Level \\
\hline $1.00-2.33$ & Low \\
$2.34-3.66$ & Mediocre \\
$3.67-5.00$ & High \\
\hline
\end{tabular}

(Source: Osman \& Marimuthu, 2010; Osman et al., 2010; Soh et al., 2012) 
Data from questionnaire was processed using Statistical Package for Social Sciences (SPSS). It was analysed using descriptive statistics and inferential statistics. For descriptive statistics, mean (M) and standard deviation (SD) of inventive thinking and its sub-construct were calculated. For inferential statistics, two-way ANOVA were employed to determine whether different gender and previous school location affect the level of inventive thinking and its subconstructs.

\section{RESULTS AND DISCUSSION}

This quantitative study involved 240 preparatory course science students (18-19 years old). They were Year One students at two Majlis Amanah Rakyat (MARA) colleges that conducted International Baccalaureate Diploma Programme (IBDP). They were excelled in Malaysian Certificate of Education and passed an entrance interview conducted by MARA. MARA is a government agency that facilitates, guides and trains Bumiputera in business and industry areas (Majlis Amanah Rakyat, 2018). They will be sponsored by MARA to pursue their first degrees in sciences such as medicine, engineering, nanotechnology, biomedical, biotechnology and so on. The respondent' profile is presented in Table 3.

Table 3. Respondents' profile

\begin{tabular}{lcc}
\hline Background & Frequency & $\%$ \\
\hline Gender & & \\
Male & 97 & 40.4 \\
Female & 143 & 59.6 \\
Former school location & & \\
Urban & 161 & 67.1 \\
Rural & 79 & 32.9 \\
\hline
\end{tabular}

Note: Former school location means the location of the secondary school either urban or rural.

\section{Inventive Thinking}

The findings revealed that the levels of all sub-constructs of inventive thinking were high $(\mathrm{M}=3.71-4.30)$ except for creativity that revealed mediocre $(M=3.53)$. Self-regulation has the highest mean $(M=4.30, S D=0.49)$ whereas creativity has the lowest mean $(\mathrm{M}=3.53, \mathrm{SD}=0.39)$. Nevertheless, the level of inventive thinking among preparatory course science students was high. The sub-constructs of inventive thinking are set out in Table 4. 
Table 4. Sub-construct of inventive thinking

\begin{tabular}{lccc}
\hline Sub-construct & Mean & SD & Level \\
\hline Flexibility & 3.71 & 0.54 & High \\
Self-regulation & 4.30 & 0.49 & High \\
Curiosity & 4.14 & 0.52 & High \\
Creativity & 3.53 & 0.39 & Mediocre \\
Risk taking & 3.94 & 0.50 & High \\
Higher order thinking & 3.97 & 0.51 & High \\
Inventive thinking & 3.98 & 0.39 & High \\
\hline
\end{tabular}

These results implied that the level of inventive thinking among preparatory course science students was good. The students were able to think creatively and critically during problem solving to produce innovative ideas or solutions. They analyse the problem thoroughly, use available resources, suggest ideas or solutions and finally choose the best solution to overcome the problem. These activities require a high cognitive process and therefore the students should be given with real life problems so that they are trained to exercise their cognitive ability. These results were consistent with Soh (2011) that the level of inventive thinking was high for Form Four Physics students. Meanwhile, these results also agreed with Sahak et al. (2012) that the level of inventive thinking was high for secondary school in Kelantan. However, in this study, creativity was the only subconstructs that showed a mediocre level but contradict to Soh (2011) and Sahak et al. (2012) in which both studies showed risk taking was at a mediocre level.

\section{Flexibility}

As can be seen from Table 5, the level of flexibility was high $(\mathrm{M}=3.71$, $\mathrm{SD}=0.54$ ). The highest mean is shown for item D5 "During solving a problem, I plan to find information so that the problem can be solved within the given time" $(\mathrm{M}=4.07, \mathrm{SD}=0.67)$. Meanwhile, the lowest mean is shown for item D4 "I will stop trying if the problem cannot be solved" $(\mathrm{M}=3.14, \mathrm{SD}=1.16)$. Two items, D3 and D4 showed a mediocre level. Item D3 "I am not confident to solve a problem that given to me" $(\mathrm{M}=3.20, \mathrm{SD}=1.16)$ while item $\mathrm{D} 4$ "I will stop trying if the problem cannot be solved" $(\mathrm{M}=3.14, \mathrm{SD}=1.16)$. Nevertheless, the overall level of flexibility among preparatory course science students was high. These results suggest that the students were able to alter the manner of thinking, attitudes and actions in completing multiple tasks within the constraint of time and resources. 
Table 5. Item of flexibility

\begin{tabular}{llccc}
\hline No. & Item & Mean & SD & Level \\
\hline D1 & $\begin{array}{l}\text { I will positive even though I have to face unexpected } \\
\text { problem. }\end{array}$ & 4.06 & 0.71 & High \\
D2 & $\begin{array}{l}\text { During solving a problem, I always think a variety } \\
\text { method from different perspectives. }\end{array}$ & 4.10 & 0.64 & High \\
D3 $\quad \begin{array}{l}\text { I am not confident to solve a problem that is given } \\
\text { to me. }\end{array}$ & 3.20 & 1.15 & Mediocre \\
D4 & $\begin{array}{l}\text { I will stop trying if the problem cannot be solved. } \\
\text { D5 }\end{array}$ & 3.14 & 0.67 & Mediocre \\
& $\begin{array}{l}\text { During solving problem, I plan to find information so } \\
\text { that the problem can be solved within the given time. }\end{array}$ & 4.07 & 0.67 & High \\
\hline & Flexibility & 3.71 & 0.54 & high \\
\hline
\end{tabular}

\section{Self-regulation}

It is demonstrated in Table 6, the overall mean for self-regulation is high $(\mathrm{M}=4.30, \mathrm{SD}=0.49)$. All items of self-regulation demonstrated a high level. Item D9 "I set goals for my study" and D13 "I will seek help whenever I have difficulty in my study" demonstrated the highest mean $(\mathrm{M}=4.43$, $\mathrm{SD}$ for $\mathrm{D} 9=0.60, \mathrm{SD}$ for D13 = 0.64). Meanwhile item D7 "I plan strategies for my study" demonstrated the lowest mean $(\mathrm{M}=4.13, \mathrm{SD}=0.75)$. However, the level of self-regulation among preparatory course science students was at a high level. These can imply that the students were good at setting goals, making strategies to achieve the goals, managing their time and evaluating the achieved goals independently. Students who exhibit high self-regulation set orientation goals rather than performance goals. They are able to differentiate between effective and ineffective self-regulated learning strategies to accomplish their goals (Velayutham, Aldridge \& Fraser, 2011). Master goals stress on task learning, make improvement and enhance understanding whilst performance goals stress on competence or ability and how it is compared with others (Urdan \& Midgley, 2003).

\section{Curiosity}

Based on the findings presented in Table 7, the level of curiosity was high $(\mathrm{M}=4.14, \mathrm{SD}=0.52)$. All items of curiosity sub-construct were at a high level. Item D14 "I am interested to know something new and outstanding around my surrounding $(\mathrm{M}=4.45, \mathrm{SD}=0.61)$. Item $\mathrm{D} 18$ "I will always make hypotheses from my observation around my surrounding" showed the lowest mean $(\mathrm{M}=3.92, \mathrm{SD}=0.77)$. Nevertheless, overall mean was high that indicated the 
level of curiosity among preparatory course science students was high. These findings implied that the students have strong desire to know something new and this will flourish lifelong learning spirit in them.

Table 6. Item of self-regulation

\begin{tabular}{clccc}
\hline No. & Item & Mean & SD & Level \\
\hline D6 & I set goals for my study. & 4.18 & 0.69 & High \\
D7 & I plan strategies for my study. & 4.13 & 0.75 & High \\
D8 & I believe with my ability in study. & 4.25 & 0.71 & High \\
D9 & I will try my best to achieve my goal. & 4.43 & 0.60 & High \\
D10 & I develop interest towards my study. & 4.37 & 0.64 & High \\
D11 & I pay attention during lesson. & 4.32 & 0.67 & High \\
D12 & I monitor my achievement. & 4.31 & 0.73 & High \\
D13 & I will seek help whenever I have difficulty in my study. & 4.43 & 0.64 & High \\
\hline & Self-regulation & 4.30 & 0.49 & High \\
\hline
\end{tabular}

Table 7. Item of curiosity

\begin{tabular}{llccc}
\hline No. & Item & Mean & SD & Level \\
\hline D14 & $\begin{array}{l}\text { I am interested to know something new and outstanding } \\
\text { around my surrounding. }\end{array}$ & 4.45 & 0.61 & High \\
D15 & $\begin{array}{l}\text { I will further investigate on the phenomenon that I see } \\
\text { from the surrounding due to my natural curiosity. }\end{array}$ & 4.14 & 0.75 & High \\
D16 & $\begin{array}{l}\text { I will accept ideas from an outstanding person but will } \\
\text { investigate on his/her ideas. }\end{array}$ & 4.23 & 0.75 & High \\
D17 & $\begin{array}{l}\text { I will always try to learn science beyond the science } \\
\text { content given in the syllabus. }\end{array}$ & 3.98 & 0.80 & High \\
D18 & $\begin{array}{l}\text { I will always make hypotheses from my observation } \\
\text { around my surrounding. }\end{array}$ & 3.92 & 0.77 & High \\
\hline & Curiosity & 4.14 & 0.52 & High \\
\hline
\end{tabular}

\section{Creativity}

It can be seen from the data in Table 8 that the level of creativity was mediocre $(\mathrm{M}=3.52, \mathrm{SD}=0.56)$. It was the only sub-construct of inventive thinking that scored mediocre while the other sub-constructs scored high. Two items showed mediocre which are D20 "I always produce new ideas during science learning" scored mean $(\mathrm{M}=3.60, \mathrm{SD}=0.85)$ and $\mathrm{D} 21$ "I have never produced a new product from my science knowledge" scored lower mean $(\mathrm{M}=2.68$, $\mathrm{SD}=1.17$ ). These results were in accord with the study carried out by Ayob et al. 
(2012) that measured Electrical Engineering undergraduate students' creativity who participated in a national robotic design competition. It was found out that the creativity level of students was average. Besides that, these findings seem to be consistent with Abdullah and Osman (2010) that primary school students in Brunei showed low mean scores on creativity, higher order thinking and sound reasoning. This finding can also be supported by Jiboye et al. (2019) that revealed no significant correlation between creativity and mental ability among high achieving students.

Some research studies investigated creativity itself among undergraduate science students. The results of a study carried out by Alias (2009) reported that the creativity level of science programme students at the Faculty of Education in one of local university was low. On the other hand, Saad (2009) studied the practice of creativity and innovation among engineering students in the Final Year Project. The results revealed that there was a less control of creativity and innovation during the implementation of the Final Year Project. From another perspective, a study conducted by Cheng (2011) on science teachers in Hong Kong mentioned that the science curriculum in Hong Kong was too deep. As a result, they cannot train the students much on creativity but just concentrate on the subject content. Besides that, Daud, Omar, Turiman and Osman (2012) suggested that among the challenges that might hinder the inculcation of creativity are the teachers' knowledge to teach creativity, teachers' emphasis on creativity teaching and students who are shy and not willing to show their creativity. The inculcation of creativity among science students should be given attention since their primary education until tertiary education so that they can produce science innovation in this creative economy era.

Table 8. Item of creativity

\begin{tabular}{llccc}
\hline No. & Item & Mean & SD & Level \\
\hline D19 & I will test the proposed hypotheses. & 3.69 & 0.86 & High \\
D20 & I always produce new ideas during science learning. & 3.60 & 0.85 & Mediocre \\
D21 & $\begin{array}{l}\text { I have never produced a new product from my } \\
\text { science knowledge. }\end{array}$ & 2.68 & 1.17 & Mediocre \\
D22 & I always consider things from various aspects. & 4.14 & 0.62 & High \\
\hline & Creativity & 3.52 & 0.56 & Mediocre \\
\hline
\end{tabular}




\section{Risk Taking}

As shown in Table 9, the level of risk taking was high $(\mathrm{M}=3.95, \mathrm{SD}=0.50)$. All items in risk taking sub-construct were at a high level. Item D24 "I like to evaluate my strengths and weaknesses" indicated the highest mean $(\mathrm{M}=4.23$, $\mathrm{SD}=0.70)$. Item D27 "I am not afraid to make mistakes" the lowest mean $(\mathrm{M}=3.79, \mathrm{SD}=0.87)$. However, overall mean was high that indicated the level of risk taking among preparatory course science students was high. This can be implied that the students were willing to place something that they valued where it can be lost or damaged. They may go beyond their comfort zones to try out new routines or adventures.

Table 9. Item of risk taking

\begin{tabular}{|c|c|c|c|c|}
\hline No. & Item & Mean & SD & Level \\
\hline D23 & I always feel energetics to generate ideas on my own. & 3.93 & 0.77 & High \\
\hline D24 & I like to evaluate my strengths and weaknesses. & 4.23 & 0.70 & High \\
\hline D25 & I will always alert towards changes around my surrounding. & 3.95 & 0.80 & High \\
\hline D26 & $\begin{array}{l}\text { I will take up a challenging science task even though I have } \\
\text { no confident to do it. }\end{array}$ & 3.89 & 0.81 & High \\
\hline D27 & I am not afraid to make mistakes. & 3.79 & 0.87 & High \\
\hline D28 & $\begin{array}{l}\text { I will continue critically evaluate and make improvements } \\
\text { toward my ideas after I have completed the challenging } \\
\text { science task. }\end{array}$ & 4.03 & 0.66 & High \\
\hline D29 & $\begin{array}{l}\text { I am willing to accept science task that leads me to do } \\
\text { mistakes. }\end{array}$ & 3.81 & 0.86 & High \\
\hline & Risk taking & 3.95 & 0.50 & High \\
\hline
\end{tabular}

\section{Higher Order Thinking}

Table 10 indicates that the level of higher order thinking was high $(\mathrm{M}=3.97$, $\mathrm{SD}=0.51)$. All items of this sub-construct were at a high level. Item D30 "I will identify the important elements present in the given problem" indicated the highest mean $(\mathrm{M}=4.07, \mathrm{SD}=0.55)$. Meanwhile, item D31 "I will find the relationship between important elements from a problem with their analysis using electronic devices" indicated the lowest mean $(\mathrm{M}=3.88, \mathrm{SD}=0.78)$. Nevertheless, overall mean was high that indicated the level of higher order thinking among preparatory course science students was high. The findings implied that the students were able to give informed, sound, thoughtful, judgement and conclusion through their creative problem-solving thinking. In science learning, the students who possess higher order thinking skills are able to apply their 
knowledge to another unfamiliar problems, situations, uncertainties and dilemmas through problem solving and various science process skills (Miri, David, \& Uri, 2007; Pappas, Pierrakos, \& Nagel, 2013). These higher order thinking skills are essential for them to solve problem in acquiring scientific knowledge and apply that knowledge in facing complex problems at workplace.

Table 10. Item of higher order thinking

\begin{tabular}{llccc}
\hline No. & Item & Mean & SD & Level \\
\hline D30 & $\begin{array}{l}\text { I will identify the important elements present in the } \\
\text { given problem. }\end{array}$ & 4.07 & 0.55 & High \\
D31 & $\begin{array}{l}\text { I will find the relationship between important elements } \\
\text { in a problem with the analysis using electronic devices. }\end{array}$ & 3.88 & 0.78 & High \\
D32 & $\begin{array}{l}\text { I will set important elements identified in the problem. } \\
\text { D33 }\end{array}$ & 3.96 & 0.64 & High \\
& $\begin{array}{l}\text { problem. } \\
\text { I will evaluate the limitation and information gained }\end{array}$ \\
when I solve the problem. & 4.03 & 0.68 & High \\
D35 & $\begin{array}{l}\text { I always develop new methods based on present } \\
\text { information. }\end{array}$ & 3.91 & 0.74 & High \\
\hline & Higher order thinking & 3.97 & 0.51 & High \\
\hline
\end{tabular}

\section{The Effects of Gender and Former School Location on the Levels of Inventive Thinking}

As presented in Table 11, all degrees of significance for gender, former school location and gender*former school location were greater than 0.05 . These implied that there were no significant differences in the level of inventive thinking based on gender and former school location. There was also no interaction between gender and former school location on the level of inventive thinking as illustrated in Figure 2. Consequently, gender and former school location gave no effect on the level of inventive thinking among preparatory course science students. A probable explanation would be the respondents involved in this study have been selected and fulfilled the requirements set by MARA. Therefore, there was no significance difference for the effect of gender and former school location on the level of inventive thinking. All students possessed high ability in both academic and non-academic aspects including inventive thinking. Furthermore, these findings were in line with the findings from the study conducted by Sahak et al. (2012). The study revealed that the location does not affect any of the subconstructs of inventive thinking studied. This gave an implication that the level of inventive thinking was not limited to be developed among the students in the city 
alone. Majority would expect that the exposure of urban students on the current needs of nation and the world is higher than the rural students is proven wrong. Rural students in this study showed their potential too to compete with students from urban schools in terms of building inventive thinking in themselves

Table 11. Two-way ANOVA of inventive thinking based on gender and former school location.

\begin{tabular}{lccccc}
\hline Main effect & $\begin{array}{c}\text { Total } \\
\text { square }\end{array}$ & Df & $\begin{array}{c}\text { Mean } \\
\text { square }\end{array}$ & $F$-value & $\begin{array}{c}\text { Degree if } \\
\text { significant }\end{array}$ \\
\hline Gender & 0.007 & 1 & 0.007 & 0.048 & 0.826 \\
Former school location & 0.001 & 1 & 0.001 & 0.006 & 0.938 \\
Gender*Former school location & 0.305 & 1 & 0.305 & 2.042 & 0.154 \\
Error & & & 35.240 & 236 & 0.149 \\
\hline Total & & & 3837.363 & 240 & \\
\hline
\end{tabular}

Note: Significant at $p=0.05$.

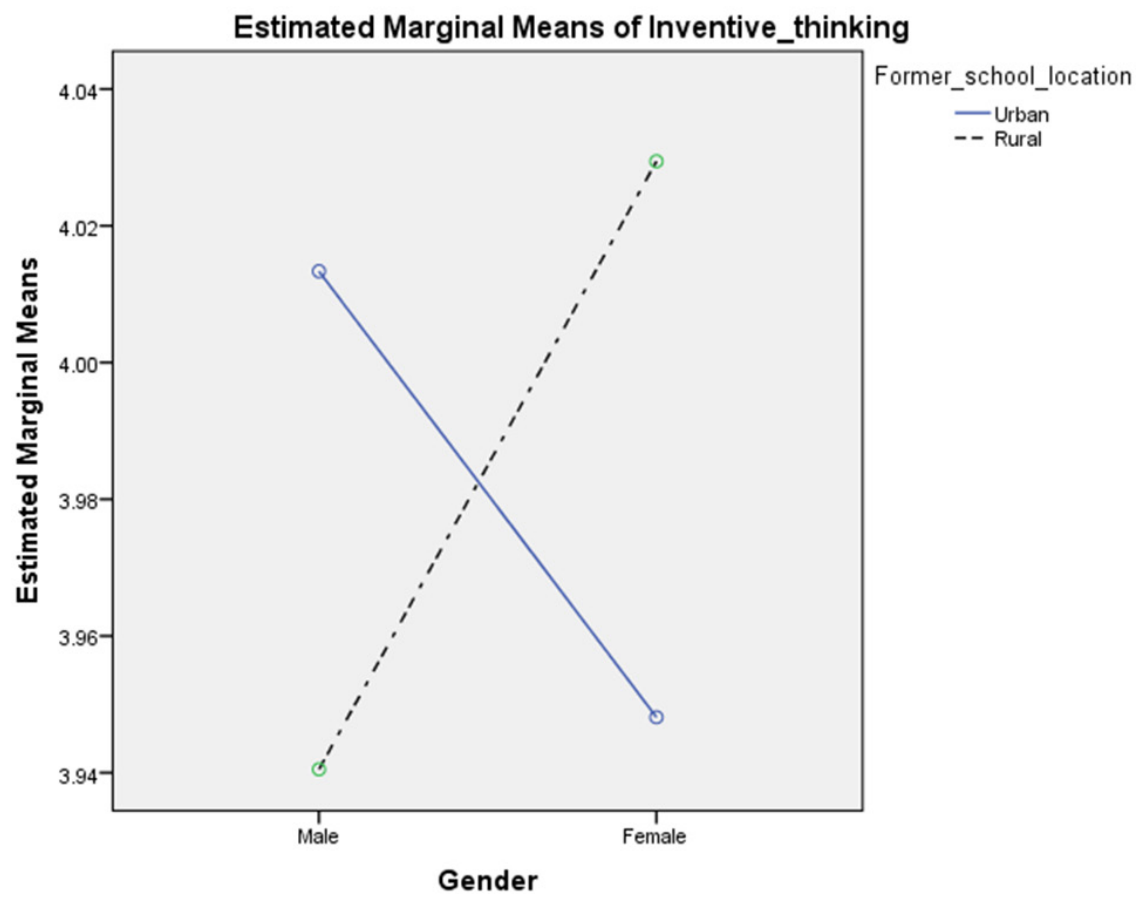

Figure 2. Interaction between gender and former school location on inventive thinking. 


\section{The Effects of Gender and Former School Location on the Levels of Flexibility}

Table 12 demonstrates that all degrees of significance for gender, location and gender*location were greater than 0.05 . These give indication that there were no significant differences in the level of flexibility based on gender and former school location. Meanwhile, there was also no interaction between gender and former school location on the level of flexibility as shown in Figure 3. As a result, the level of flexibility among preparatory course science students was not affected by gender or former school location.

Table 12. Two-way ANOVA of flexibility based on gender and former school location

\begin{tabular}{lccccc}
\hline Main effect & $\begin{array}{c}\text { Total } \\
\text { square }\end{array}$ & Df & $\begin{array}{c}\text { Mean } \\
\text { square }\end{array}$ & $F$-value & $\begin{array}{c}\text { Degree if } \\
\text { significant }\end{array}$ \\
\hline Gender & 0.083 & 1 & 0.083 & 0.281 & 0.597 \\
Former school location & 0.032 & 1 & 0.032 & 0.110 & 0.741 \\
Gender*Former school location & 0.679 & 1 & 0.679 & 2.306 & 0.130 \\
Error & & & 35.240 & 236 & 0.149 \\
\hline Total & & & 3837.363 & 240 &
\end{tabular}

Note: Significant at $p=0.05$.

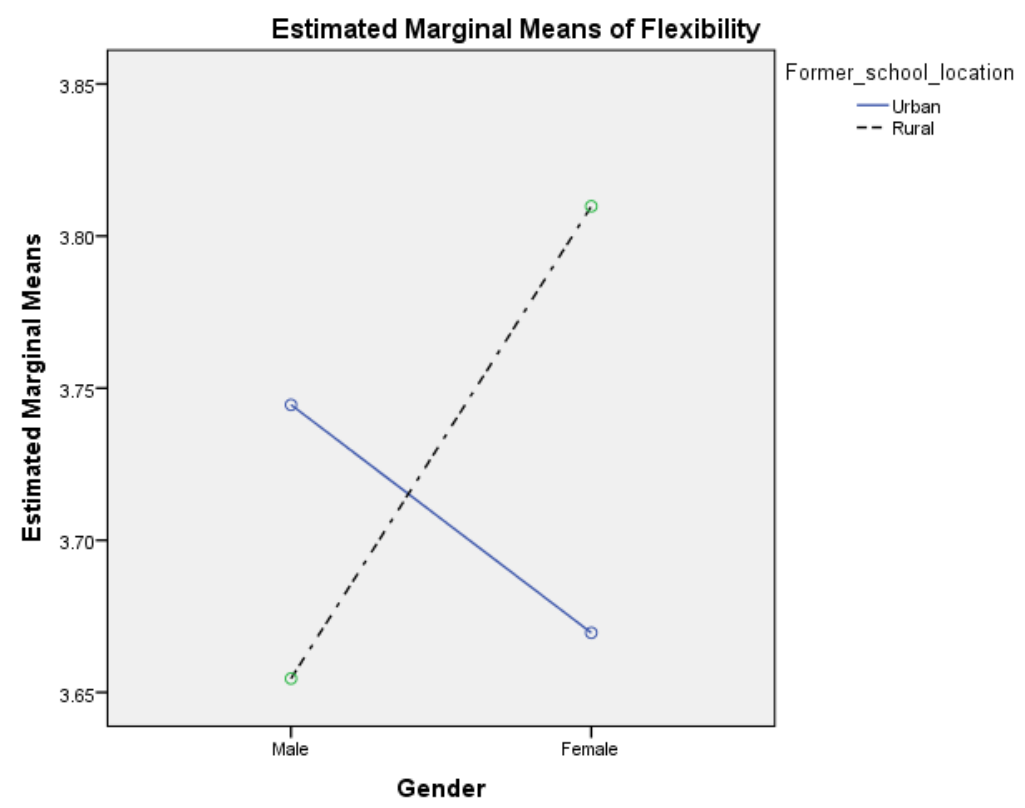

Figure 3. Interaction between gender and former school location on flexibility. 


\section{The Effects of Gender and Former School Location on the Levels of Self- Regulation}

Based on the findings in Table 13, all degrees of significance for gender, location and gender*former school location were greater than 0.05 . These findings indicated that there were no significant differences in the levels of self-regulation based on gender and former school location. In addition, there was no interaction between gender and former school location on the level of self-regulation as illustrated in Figure 4. Consequently, gender and former school location gave no effect on the level of self-regulation among preparatory course science students.

Table 13. Two-way ANOVA of self-regulation based on gender and former school location

\begin{tabular}{lccccc}
\hline Main effect & $\begin{array}{c}\text { Total } \\
\text { square }\end{array}$ & Df & $\begin{array}{c}\text { Mean } \\
\text { square }\end{array}$ & $F$-value & $\begin{array}{c}\text { Degree if } \\
\text { significant }\end{array}$ \\
\hline Gender & 0.285 & 1 & 0.285 & 1.207 & 0.273 \\
Former school location & 0.032 & 1 & 0.032 & 0.134 & 0.714 \\
Gender*Former school location & 0.591 & 1 & 0.591 & 2.505 & 0.115 \\
Error & & & 55.659 & 236 & 0.236 \\
\hline Total & & & 4501.005 & 240 & \\
\hline
\end{tabular}

Note: Significant at $p=0.05$.

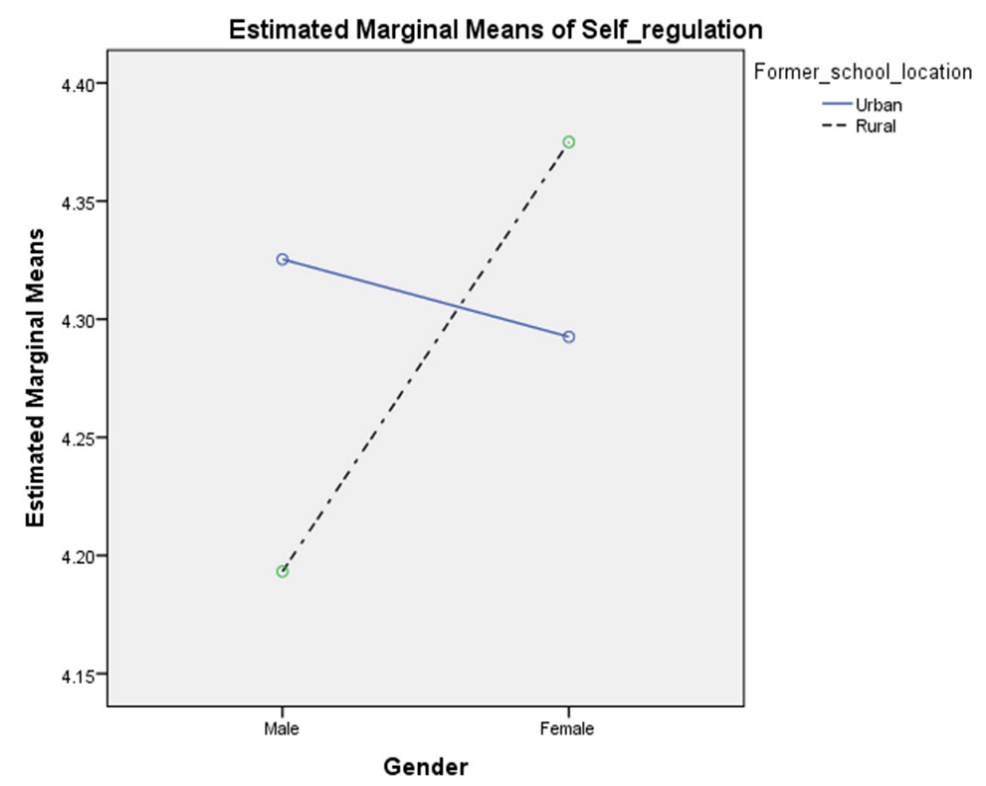

Figure 4. Interaction between gender and former school location on self-regulation 


\section{The Effects of Gender and Former School Location on the Levels of Curiosity}

Table 14 displays that all degrees of significance for gender, location and gender*location were greater than 0.05 . These findings revealed that there were no significant differences in the levels of curiosity based on gender and former school location. Meanwhile, there was also no interaction between gender and former school location on the level of flexibility as shown in Figure 5. Therefore, the levels of creativity among preparatory course science students were not affected by gender and former school location.

Table 14. Two-way ANOVA of curiosity based on gender and former school location

\begin{tabular}{lccccc}
\hline Main effect & $\begin{array}{c}\text { Total } \\
\text { square }\end{array}$ & Df & $\begin{array}{c}\text { Mean } \\
\text { square }\end{array}$ & $F$-value & $\begin{array}{c}\text { Degree if } \\
\text { significant }\end{array}$ \\
\hline Gender & 0.049 & 1 & 0.049 & 0.183 & 0.669 \\
Former school location & 0.593 & 1 & 0.593 & 2.220 & 0.138 \\
Gender*Former school location & 0.063 & 1 & 0.063 & 0.237 & 0.627 \\
Error & & & 63.086 & 236 & 0.267 \\
\hline Total & & & 4185.640 & 240 & \\
\hline
\end{tabular}

Note: Significant at $p=0.05$.

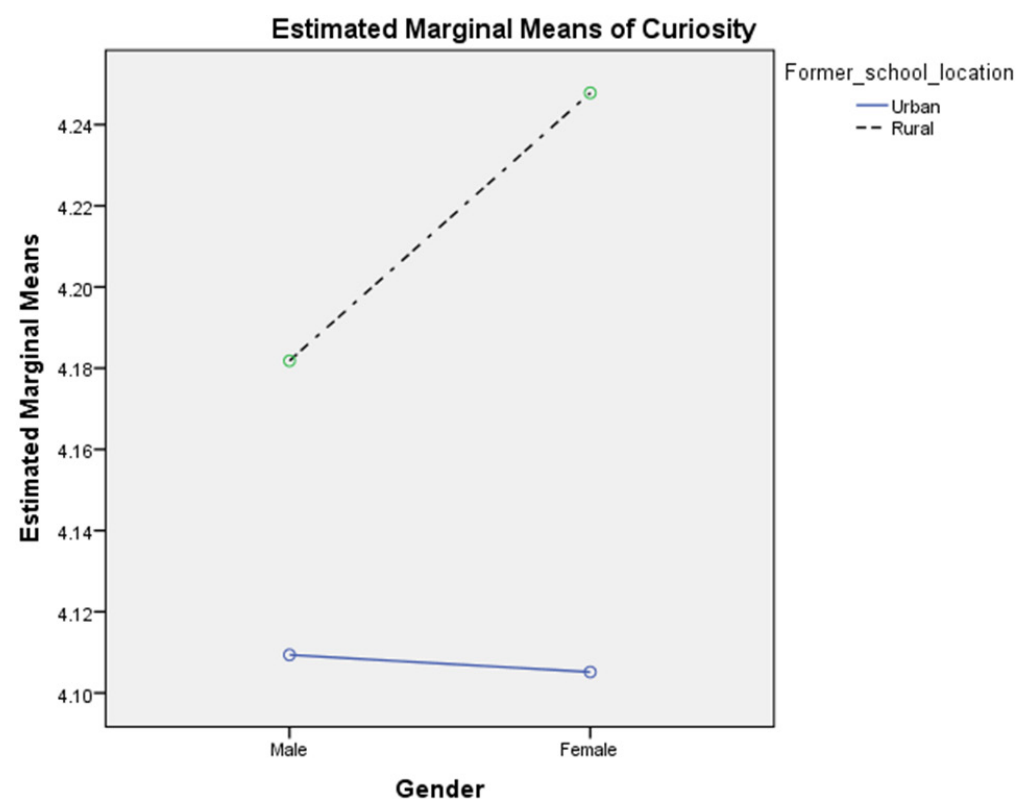

Figure 5. Interaction between gender and former school location on curiosity 


\section{The Effects of Gender and Former School Location on the Levels of Creativity}

It is demonstrated in Table 15 that all degrees of significance for gender, location and gender*former school location on creativity were greater than 0.05 . These implied that there were no significant differences in the level of creativity based on gender and former school location. Meanwhile, there was also no interaction between gender and former school location on the level of creativity as shown in Figure 6. Therefore, gender and former school location gave no effect on the levels of creativity among preparatory course science students. These results agreed with the findings of Naderi et al. (2009) that found no significant difference in creativity based on gender among undergraduate students. Meanwhile, there was no evidence on the effect of gender and racial on the creativity (Baer \& Kaufman, 2008; Kaufman et al., 2010).

Table 15. Two-way ANOVA of creativity based on gender and former school location

\begin{tabular}{lccccc}
\hline Main effect & $\begin{array}{c}\text { Total } \\
\text { square }\end{array}$ & Df & $\begin{array}{c}\text { Mean } \\
\text { square }\end{array}$ & $F$-value & $\begin{array}{c}\text { Degree if } \\
\text { significant }\end{array}$ \\
\hline Gender & 0.135 & 1 & 0.135 & 0.435 & 0.510 \\
Former school location & 0.147 & 1 & 0.147 & 0.475 & 0.492 \\
Gender*Former school location & 0.351 & 1 & 0.351 & 1.133 & 0.288 \\
Error & & & 73.088 & 236 & 0.310 \\
\hline Total & & & 3061.313 & 240 & \\
\hline
\end{tabular}

Note: Significant at $p=0.05$. 


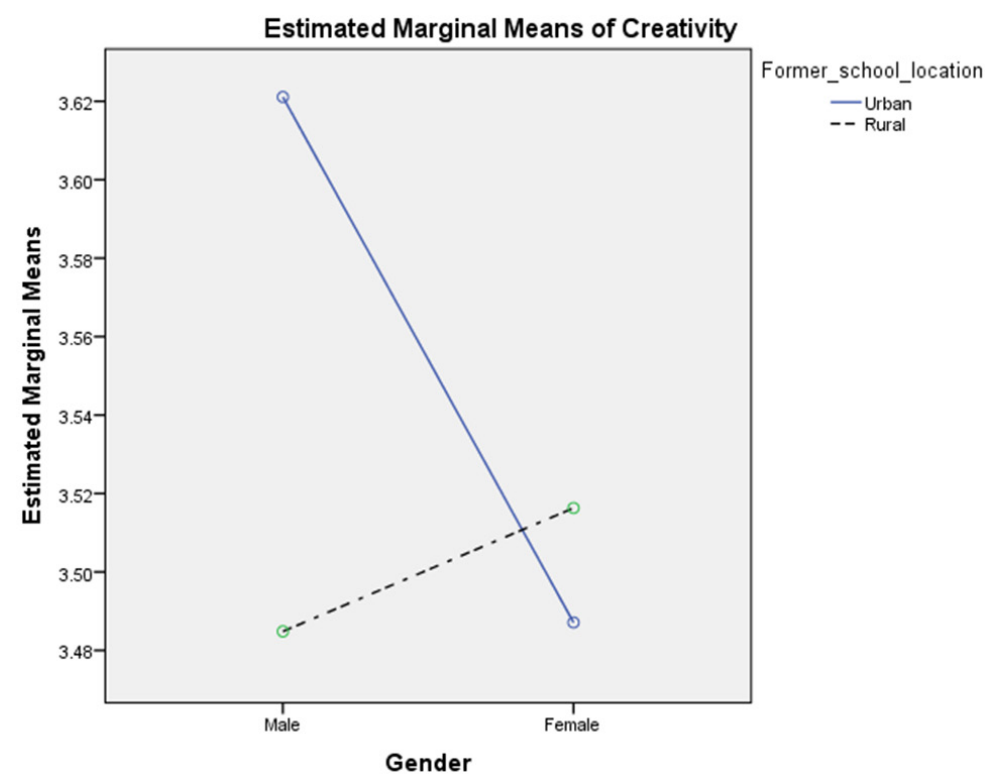

Figure 6. Interaction between gender and former school location on creativity

\section{The Effects of Gender and Former School Location on the Levels of Risk Taking}

Based on the findings in Table 16, all degrees of significance for gender, location and gender*former school location on risk taking were greater than 0.05 . These findings indicated that there were no significant differences in the level of risk taking based on gender and former school location. In addition, there was no interaction between gender and former school location on the levels of self-regulation as illustrated in Figure 7. Hence, the level of risk taking among preparatory course science students was not affected by gender and former school location.

Table 16. Two-way ANOVA of risk taking based on gender and former school location

\begin{tabular}{lccccc}
\hline Main effect & $\begin{array}{c}\text { Total } \\
\text { square }\end{array}$ & Df & $\begin{array}{c}\text { Mean } \\
\text { square }\end{array}$ & $F$-value & $\begin{array}{c}\text { Degree if } \\
\text { significant }\end{array}$ \\
\hline Gender & 0.205 & 1 & 0.205 & 0.823 & 0.365 \\
Former school location & 0.105 & 1 & 0.105 & 0.423 & 0.516 \\
Gender*Former school location & 0.305 & 1 & 0.305 & 1.226 & 0.269 \\
Error & & & 58.751 & 236 & 0.249 \\
\hline Total & & & 3796.265 & 240 & \\
\hline
\end{tabular}

Note: Significant at $p=0.05$. 


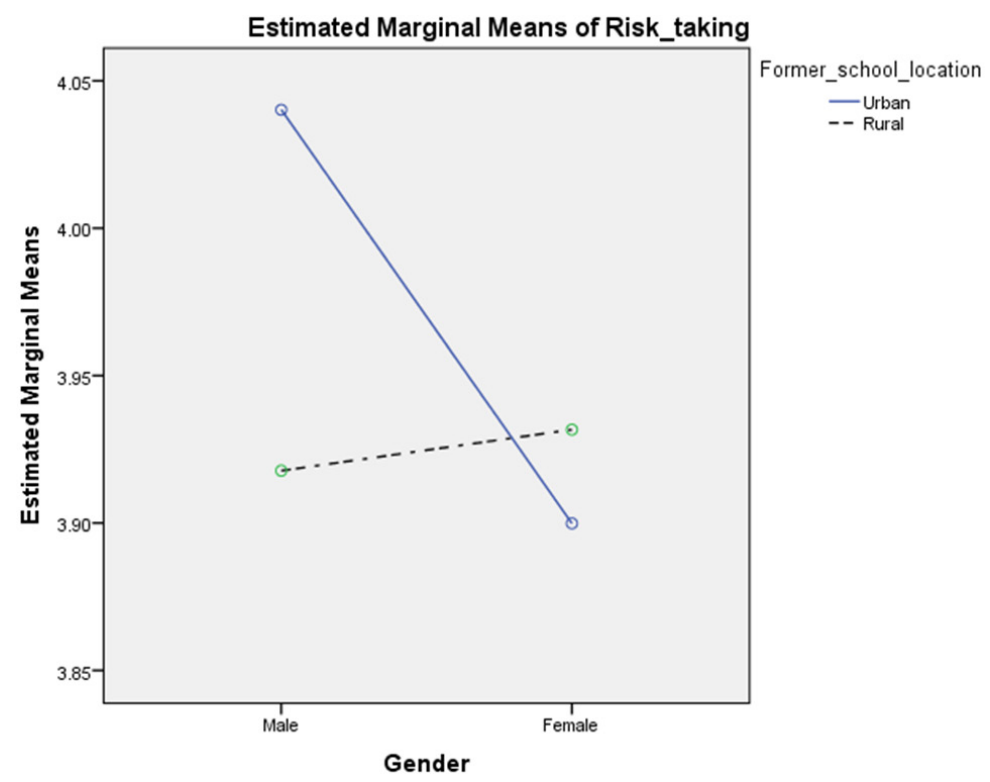

Figure 7. Interaction between gender and former school location on risk taking

\section{The Effects of Gender and Former School Location on the Levels of Higher Order Thinking}

As presented in Table 17, all degrees of significance for gender, former school location and gender*former school location on higher order thinking were greater than 0.05 . These gave implication that there were no significant differences in the level of higher order thinking based on gender and former school location. Meanwhile, there was also no interaction between gender and former school location on the level of higher order thinking as illustrated in Figure 8. As a result, gender and former school location gave no effect on the level of higher order thinking among preparatory course science students. These results on the effect of gender were consistent with Saido et al. (2015) that measured the level of higher order thinking skills among 7th grade science students in the Iraqi-Kurdistan region. The findings demonstrated that there was no significant difference in the level of higher order thinking skills between male and female students. 
Table 17. Two-way ANOVA of higher order thinking based on gender and former school location

\begin{tabular}{lccccc}
\hline Main effect & $\begin{array}{c}\text { Total } \\
\text { square }\end{array}$ & Df & $\begin{array}{c}\text { Mean } \\
\text { square }\end{array}$ & $F$-value & $\begin{array}{c}\text { Degree if } \\
\text { significant }\end{array}$ \\
\hline Gender & 0.016 & 1 & 0.016 & 0.059 & 0.808 \\
Former school location & 0.069 & 1 & 0.069 & 0.261 & 0.610 \\
Gender*Former school location & 0.075 & 1 & 0.075 & 0.285 & 0.594 \\
Error & & & 62.223 & 236 & 0.264 \\
\hline Total & & & 3850.840 & 240 & \\
\hline
\end{tabular}

Note: Significant at $p=0.05$.

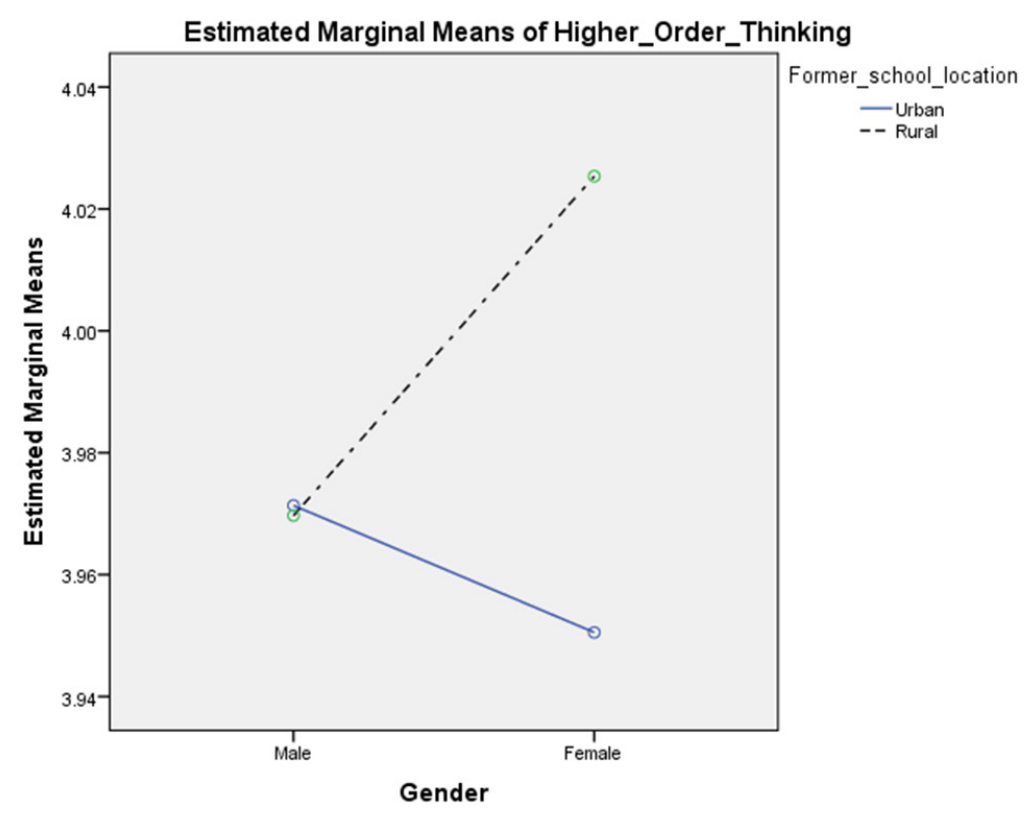

Figure 8. Interaction between gender and former school location on higher order thinking

\section{CONCLUSION}

Inventive thinking is an imperative skill to be acquired by students for the life in this complex and changing knowledge economy. This study has examined the level of inventive thinking among preparatory course science students at two MARA colleges. The overall level of inventive thinking was high. All subconstructs of inventive thinking were at a high level except for creativity that was at a mediocre level. The current findings have important implications for 
teacher, curriculum developer and education administrator to enhance creativity. Creativity is a crucial skill in this 21 st century especially for the science students to create innovations. At the same time, other sub-constructs of the inventive thinking should be fostered as well since these are the essential skills for students to solve complex problem and diverse challenges in this knowledge economy. With regard to gender and former school location, there were no significant differences in the levels of inventive thinking. This may due to the tight selection carried out by MARA for the students to enter these MARA colleges. They must obtain good result in Malaysia Certificate of Examination and pass an entrance interview conducted by MARA. It can be concluded that the students were homogeneous and have no variations in the level of inventive thinking based on gender and former school location. Therefore, this study can be expanded to other foundation courses at local universities or matriculation colleges that have larger samples and populations as well as broader students' background.

\section{REFERENCES}

Abdullah, M., \& Osman, K. (2010). Scientific inventive thinking skills among primary students in Brunei. Procedia Social and Behavioral Sciences, 7(C), 294-301. https://doi.org/10.1016/j.sbspro.2010.10.041

Alias, S. H. (2009). Tahap kreativiti di kalangan pelajar program Sains di Fakulti Pendidikan, Universiti Teknologi Malaysia: A thesis in Science Education. Unpublished Master's thesis, Universiti Teknologi Malaysia.

Amabile, T. M. (1996, January). Creativity and innovation in organisations. Harvard Business School background note, 396-239.

Arsad, M. N. (2011). Penyepaduan kemahiran abad ke-21 dalam pengajaran dan pembelajaran Biologi. Unpublished Master's thesis, Universiti Kebangsaan Malaysia.

Arsad, M. N., Osman, K. \& Soh, T. M. T. (2011). Instrument development for $21^{\text {st }}$ century skills in Biology. Procedia Social and Behavioral Sciences, 15, 1470-1474. https://doi.org/10.1016/j.sbspro.2011.03.312

Ayob, A, Hussain, A., Mustaffa, M. M., \& Abdul Majid, R. (2012). Assessment of creativity in electrical engineering. Procedia - Social and Behavioral Sciences, 60, 463-467. https://doi.org/10.1016/j.sbspro.2012.09.407

Baer, J. \& Kaufman, J. C. (2008). Gender differences in creativity. Journal of Creative Behavior, 42(2), 75-105. https://doi.org/10.1002/j.2162-6057.2008.tb01289.x

Boyaci, Ş. D. B., \& Atalay, N. (2016). A scale development for 21st Century skills of primary school students: a validity and reliability study. International Journal of Instruction, 9(1), 113-133. https://doi.org/10.12973/iji.2016.9111a

Cheng, M. Y. V. (2011). Infusing creativity into Eastern classroom: Evaluations from students' perspectives. Journal of Thinking Skills and Creativity, 6, 67-87. https://doi.org/10.1016/j.tsc.2010.05.001 
Cooper, R. (2000). Information technology development creativity: A case study of attempted radical change. MIS Quarterly, 24(2), 245-276. https://oi.org/ $10.2307 / 3250938$

Daly, S. R., Mosyjowski, E. A., Oprea, S.L., Huang-Saad, A. \& Seifert, C. M. (2016). College students' views of creative process instruction across disciplines. Thinking Skills and Creativity, 22, 1-13. https://doi.org/10.1016/j.tsc.2016.07 .002

Daud, A. M., Omar, J., Turiman, P., \& Osman, K. (2012). Creativity in science education. Procedia - Social and Behavioral Sciences, 59, 467-474. https://doi.org/10.1016/ j.sbspro.2012.09.302

Egan, A., Maguire, R., Christophers, L., \& Rooney, B. (2017). Developing creativity in higher education for $21^{\text {st }}$ century learners: A protocol for a scoping review. International Journal of Educational Research, 82, 21-27. https://doi.org/ 10.1016/j.ijer.2016.12.004

Fraenkel, J. R., Wallen, N. E., \& Hyun, H. H. (2013). How to design and evaluate research in education (8th ed.). New York: Mc-Graw Hill.

Greiff, S., Niepel, C., \& Wustenberg, S. (2015). $21^{\text {st }}$ century skills; Recent advancement and international developments. Thinking Skills and Creativity, 8, 1-3. https://doi.org/10.1016/j.tsc.2015.04.007

Häkkinen, P., Järvelä, S., Mäkitalo-Siegl, K., Ahonen, A., Näykki, P., \& Valtonen, T. (2016): Preparing teacher-students for twenty-first-century learning practices (PREP 21): A framework for enhancing collaborative problem-solving and strategic learning skills, Teachers and Teaching, 23(1) [Online]. https://doi.org/ 10.1080/13540602.2016.1203772

Husin, W. W. N. F., Arsad, M. N., Othman, O., Halim, L., Rasul, M. S., Osman, K., \& Iksan, Z. (2016). Fostering students' 21st century skills through Project Oriented Problem Based Learning (POPBL) in integrated STEM education. Asia-Pacific Forum on Science Learning and Teaching, 17(1), Article 3.

Jerome, C., Lee, J. A. -C., \& Ting, S. -H. (2017). What students really need: instructional strategies that enhance higher order thinking skills (HOTS) among UNIMAS undergraduates. International Journal of Business Society, 8(S4), 661-668.

Jiboye, T. F., Salaudeen, G. O., Adejumo, O. O., \& Aikomo, D. O. (2019). Mental ability, Self-esteem and learning styles as correlate of creativity among high achieving secondary school students in Oyo State. International Journal of Innovation, Creativity and Change, 4(4), 24-43.

Kamprath, M., \& Mietzner, D. (2015). The impact of sectorial changes on individual competences: A reflective scenario-based approach in the creative industries. Technology Forecast Social Change, 95, 252-275. https://doi.org/10.1016/j. techfore.2015.01.011

Kaufman, J. C., Baer, J., Agars, M. D., \& Loomis, D. (2010). Creativity stereotypes and the consensual assessment technique. Creativity Research Journal, 22(2), 200-205. https://doi.org/10.1080/10400419.2010.481529 
Kivunja, C. (2014). Innovative pedagogies in higher education to become effective teachers of 21 st century skills: Unpacking the learning and innovations skills domain of the new learning paradigm. International Journal of Higher Education, 3(4), 37-48. https://doi.org/10.5430/ijhe.v3n4p37

Koh, J. H. L., Chai, C. S., Wong, B., \& Hong, H.-Y. (2015). Design thinking and 21st century skills. In J. H. L. Koh, C. S. Chai, B. Wong, \& H.-Y. Hong (Eds.), Design thinking for education: Conceptions and applications in teaching and learning (pp. 33-46). Singapore: Springer. https://doi.org/10.1007/978-981-287 $-444-3 \quad 3$

Majlis Amanah Rakyat. (2018). Pengenalan dan sejarah. Retrieved 25 September 2018, from http://www.mara.gov.my/en/pengenalan-sejarah

Miri, B., David, B-C., \& Uri, Z. (2007). Purposely teaching for the promotion of Higher Order Thinking Skills: A case of critical thinking. Research in Science Education, 37(4), 353-369. https://doi.org/10.1007/s11165-006-9029-2

Naderi, H., Abdullah, R., Aizan, H. T., Sharir, J., \& Kumar, V. (2009). Creativity, age and gender as predictors of academic achievement among undergraduate students. Journal of American Science, 5(5), 101-112.

NCREL. (2003). Engauge ${ }^{\circledR} 21$ st century skills: Literacy in the digital age. North Central Regional Educational Laboratory and the Metiri Group. Retrieved from http://www.grrec.ky.gov/SLC_grant/engauge21st_Century_Skills.pdf

Newton, L. D., \& Newton, D. P. (2014). Creativity in 21st-century education. Prospects, 44(4), 575-589. https://doi.org/10.1007/s11125-014-9322-1

Neubert, J. C., Mainert, J., Kretzschmar, A., \& and Greiff, S. (2015). The assessment of 21 st century skills in industrial and organizational psychology: Complex and collaborative problem solving. Industrial and Organizational Psychology, 8, 238-268. https://doi.org/10.1017/iop.2015.14

Osman, K. \& Marimuthu, N. (2010). Setting new learning targets for the 21 st century science education in Malaysia. Procedia - Social and Behavioral Sciences, 2, 737-3741. https://doi.org/10.1016/j.sbspro.2010.03.581

Osman, K., Soh, T. T. M., \& Arsad, N. M. (2010). Development and validation of the Malaysian 21st century skills instrument (M-21CSI) for science students. World Conference on Learning, Teaching and Administration (WC-LT\&A 2010). Procedia - Social and Behavioral Science, 9, 599-603. https://doi.org/10.1016/j. sbspro.2010.12.204

P21 Skills. (2011). Framework for 21st century learning. Partnership for 21 st century skills. Retrieved 27 September 2018, from http://www.p21.org/about-us/p21framework

Pappas, E., Pierrakos, O., \& Nagel, R. (2013). Using Bloom's Taxanomy to teach sustainability in multiple contexts. Journal of Cleaner Production, 48, 54-64. https://doi.org/10.1016/j.jclepro.2012.09.039

Saad, N. (2009). Amalan kreativiti dan inovasi melalui Projek Sarjana Muda dalam kalangan pelajar Kejuruteraan di UTHM: A thesis in Engineering Education. Unpublished Master thesis, Universiti Tun Hussein Onn Malaysia. 
Sahak, S., Soh, T. M. T., \& Osman, K. (2012). Comparison of level of inventive thinking among Science and Arts Students. Procedia - Social and Behavioral Sciences, 59, 475-483. https://doi.org/10.1016/j.sbspro.2012.09.303

Saido, G. M., Siraj, S., Nordin, A. B., \& Al-Amedy, O. S. (2015). Higher Order Thinking Skills among secondary school students in science learning. The Malaysian Online Journal of Educational Science, 3(1), 13-20.

Samad, N. A., \& Osman, K. (2017). EkSTEMiT learning module and inculcation of inventive thinking. K-12 STEM Education, 3(4), 259-266.

Seman, S. C., Yusoff, W. M. W., \& Embong, R. (2017). Teachers challenges in teaching and learning for Higher Order Thinking Skills (HOTS) in primary school. International Journal of Asian Social Science, 7(7), 534-545. https://doi.org/ 10.18488/journal.1.2017.77.534.545

Serdyukov, P. (2017). Innovation in education: what works, what doesn't, and what to do about it? Journal of Research in Innovative Teaching \& Learning, 10(1), 4-33. https://www.emerald.com/insight/content/doi/10.1108/JRIT-10-2016-0007/full/ html

Soh, T. T. M. (2011). Persepsi pelajar tingkatan empat terhadap mata pelajaran Fizik serta hubungannya dengan kemahiran abad ke-21. Unpublished Master thesis, Universiti Kebangsaan Malaysia.

Soh, T. T. M., Osman, K., \& Arsad, N. M. (2012), M-21CSI: A validated $21^{\text {st }}$ century skills instrument for secondary science students. Asian Social Science, 8(16), 14701474. https://doi.org/10.5539/ass.v8n16p38

Sokol, A., Oget, D., Sonntag, M., \& Khomenko, N. (2008). The development of inventive thinking: Skills in the upper secondary language classroom. Thinking Skills \& Creativity, 3(1), 34-46. https://doi.org/10.1016/j.tsc.2008.03.001

Urdan, T., \& Midgley, C. (2003). Changes in the perceived classroom goal structure and pattern of adaptive learning during early adolescence. Contemporary Educational Psychology, 28(4), 524-551. https://doi.org/10.1016/s0361-476x(02)00060-7

van Laar, E., van Deursen, A. J. A. M., van Dijk, J. A. G. M., \& Haan, J. (2018). 21stcentury digital skills instrument aimed at working professionals: Conceptual development and empirical validation. Telematic and Informatic, 35(8), 21842200. https://doi.org/10.1016/j.tele.2018.08.006

Velayutham, S., Aldridge, J., \& Fraser, B. (2011). Development and validation of an instrument to measure students' motivation and self-regulation in science learning. International Journal of Science Education, 33(15), 2159-2179. https://doi.org/10.1080/09500693.2010.541529

Zimmerer, T., \& Scarborough, H. N. (2008). Essentials of entrepreneruship and small business management (5th ed.). Upper Saddle River: NJ: Prentice-Hall. 